ZOOLOGIA 27 (3): 331-340, June, 2010

doi: $10.1590 /$ S1984-46702010000300003

\title{
Reproductive biology of the mullet Mugil liza (Teleostei: Mugilidae) in a tropical Brazilian bay
}

\author{
Rafael J. Albieri \& Francisco G. Araújo, 2 \\ ${ }^{1}$ Laboratório de Ecologia de Peixes, Universidade Federal Rural do Rio de Janeiro. Antiga Rodovia Rio-São Paulo, km 47, \\ 23851-970 Seropédica, Rio de Janeiro, Brazil. \\ ${ }^{2}$ Corresponding author. E-mail: gerson@ufrrj.br
}

\begin{abstract}
The reproductive biology of Mugil liza Valenciennes, 1836 is described as a contribution to an elaborate management programm. A total of 243 specimens ( 89 males and 154 females) were collected in the Sepetiba Bay in south-eastern Brazil from July/2006 to June/2007. The gonadosomatic index $\left(\mathrm{I}_{\mathrm{G}}\right)$ and the sequential development of the ovaries observed through histological studies suggested that the spawning season ranged from May to August. The population reached total sexual maturity $\left(\mathrm{L}_{\mathrm{T} 100}\right)$ at 550 and $570 \mathrm{~mm}$ total length $\left(\mathrm{L}_{\mathrm{T}}\right)$ for males and females, respectively. Females attained a larger size than males, and the sex ratio was female-biased for fish larger than $500 \mathrm{~mm} \mathrm{~L}_{\mathrm{T}}$. The hepatosomatic index $\left(\mathrm{I}_{H}\right)$ was significantly related to the $\mathrm{I}_{\mathrm{G}^{\prime}}$ indicating that vitellogenesis mobilizes hepatic energy during reproduction. Mean fecundity was 3,080,000 oocytes. The presence of only two phases of oocyte development in ripe ovaries - a reserve stock and a clutch of post-vitellogenic oocytes - indicated that ovarian development is group synchronic and this species is characterized as a total spawner. The results suggest that establishing a closed fishing season from May to August and establishing a minimum size for capture of $350 \mathrm{~mm} \mathrm{~L}$ would enhance stock conservation and production for future harvest seasons.
\end{abstract}

KEY WORDS. Hepatosomatic index; oocyte development; spawning; stock conservation.

The mullet Mugil liza Valenciennes, 1836 is a coastal species distributed in the western Atlantic, from the Caribbean to Southeastern Brazil (Froese \& PAuly 2008). Overall, mullets are reported to be semi-catadromous, with the juveniles being recruited to lagoons and estuaries following a period of offshore spawning (DitTy \& Shaw 1996, Blaber 2000).

Mullets are important economic resources that support many small communities through both fishing and aquaculture (Pina \& Chaves 2005, Katselis et al. 2005). The state of Rio de Janeiro is the most important producer of M. liza in Southeast Brazil, surpassing 1,000 ton $\mathrm{x} \mathrm{yr}^{-1}$, mainly from artisanal catches (Iвама 2005). In spite of the importance of mullets to fishery resources in Rio de Janeiro, no management policies have been established for them in the Sepetiba bay, a large bay in southeastern portion of the state. One of the reasons for the latter is that wildlife managers require scientific research to take protective measures, such as imposing a "closed season,"

Mugil liza represented $99.2 \%$ of the total number of Mugilidae caught in experimental samples between 1994 and 1997 (Silva \& ARAújo 2000). In spite of its abundance, this species has been poorly studied, and little information is available on its life cycle in wild conditions (Alvarez-Lajonchere 1979, 1981, Benetti \& Netto 1991). To date, there have been no histological observations of seasonal variations in the development of the gonadal cells and the energy in the somatic tissues of $M$. liza from the Brazilian coast. The aim of this study is to describe the reproductive biology of M. liza from a coastal bay in southeastern Brazil. We test the hypothesis that the reproductive pattern of M. liza is similar to that of other mullets such as Mugil platanus Günther, 1880 (AndRade-Talmelli et al. 1996, Romagosa et al. 2000) and Mugil cephalus Linnaeus, 1758 (McDounough et al. 2003), by investigating key parameters such as gonadal development, fecundity and spawning season. Since $M$. liza is suffering a great fishing pressure in the Sepetiba Bay, we provide technical data that can contribute to the establishment of a management program.

\section{MATERIAL AND METHODS}

The Sepetiba Bay is located in the southeastern region of the Rio de Janeiro State $\left(22^{\circ} 54^{\prime}-23^{\circ} 04^{\prime} \mathrm{S}, 43^{\circ} 34^{\prime}-44^{\circ} 10^{\prime} \mathrm{W}\right.$, Fig. 1) and has an area of ca. $450 \mathrm{~km}^{2}$. The bay has two distinct zones. The inner zone, influenced by rivers and tidal creeks, has a predominantly muddy substratum and beaches that are rocky, sandy, muddy, and in places, fringed with mangrove formations. The outer zone is closer to the sea, and has a predominantly coarse and sandy substratum; rocky islands are common. About $40 \%$ of the bay area is less than $5 \mathrm{~m}$ deep; the maximum depth, up to 


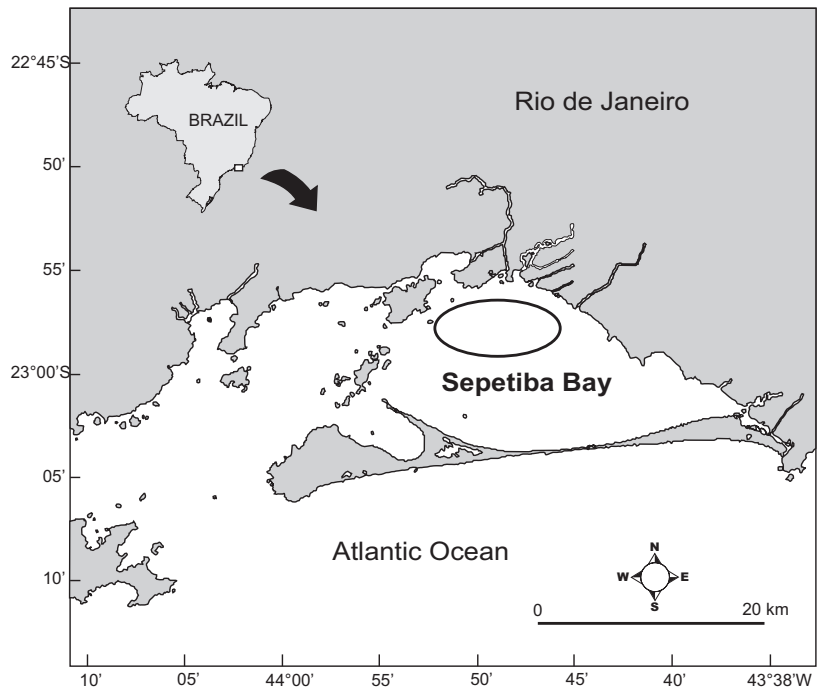

Figure 1. Sampling area (inner zone) of M. liza in the Sepetiba Bay.

$30 \mathrm{~m}$, is neart to the sea limit. Salinity ranges from 28 (rainy season) to 34 (dry season), and the temperature varies from $21.5^{\circ} \mathrm{C}$ in winter to $27^{\circ} \mathrm{C}$ in summer (Araújo et al. 2002). The tide amplitude is ca. $1 \mathrm{~m}$, and southwestern and northeastern winds contribute to moving seawater into the bay and taking bay water out toward the continental shelf, respectively (SIGNORINI 1980).

The rainfall period in the bay region occurs mainly between December and January (summer), though it can sometimes last until March. The dry period extends from May to September (winter). South quadrant winds and marine breezes discharge their moisture against the mountain cliffs around the bay and can increase the amount of rain in the dry season (BARbiÉRI \& KRONEMberg 1994). Several marine fish species enter and leave the bay to nurse, reproduce, and feed. Human impacts originate from the outskirts of Rio de Janeiro City and a few medium-sized towns that have limited agriculture and fishing as well as a growth in industry (Araújo et al. 2002).

Specimens were collected from artisanal commercial catches of the Madeira Island Fisheries Association (MIFA) from July 2006 to June 2007. MIFA uses small boats that operate in the inner zone of the Sepetiba Bay. The nets were $1500 \mathrm{~m}$ long, $3 \mathrm{~m}$ high, and had three panels of different mesh sizes $(45,50$, and $55 \mathrm{~mm}$ between opposite knots). Data on the rainfall was collected at www.rio.rj.gov.br/georio from the Sepetiba Metereological Base.

Individuals were caught randomly each month. All fishes were packed in ice and transported to the lab. Total length $\left(\mathrm{L}_{\mathrm{T}}\right)$ to the nearest $\mathrm{mm}$ was measured. Total weight $\left(\mathrm{W}_{\mathrm{T}}\right)$ and eviscerated weight $\left(\mathrm{W}_{\mathrm{E}}\right)$ were measured to the nearest gram, and liver weight $\left(\mathrm{W}_{\mathrm{L}}\right)$ and gonad weight $\left(\mathrm{W}_{\mathrm{G}}\right)$ were determined to a precision of $0.01 \mathrm{~g}$. Gonads were preserved in $70 \%$ alcohol after four hours in Bouin's solution. Gonads at the ripe stage were kept in Gilson fluid for fecundity estimation. Macroscopic description of the maturation stages of the gonads were based on shape, size, color, percent occupation of the coelomatic cavity, and blood irrigation. In addition, the color, size, and degree of oocyte visualization were also considered.

Small pieces of gonads were taken from preserved samples. These pieces were dehydrated by a graded ethanol series, embedded in paraffin wax, cut into $5 \mu \mathrm{m}$ sections, and then stained with haematoxylin-eosin. The terminology used to describe the development of oocytes and testicular cells in histological sections followed the terminology described by WeST (1990) and KANAK \& TACHIHARA (2008) with slight modifications. By examining cross-sections of different parts of the gonads, we determined that there were no regional differences in the course of gametogenesis.

Size structure for each sex was assessed by distribution of length frequency. Differences in the sex ratios of the size classes were tested with a Chi-square $\left(\chi^{2}\right)$ test. The relationship between proportion of mature fish $(\mathrm{P})$ in each length interval was described by logistic model, $\mathrm{P}=1 /\left(1+\mathrm{e}^{-\left(\mathrm{a}+\mathrm{bL}_{\mathrm{T}}\right)}\right)$ where, $\mathrm{a}$ and $\mathrm{b}$ are constants and can be estimated by procedure NLin based on 89 males and 154 females. Size at first maturity $\left(\mathrm{L}_{\mathrm{T} 50}\right)$ and size when the whole population was mature $\left(\mathrm{L}_{\mathrm{T} 100}\right)$ was then obtained by substituting $\mathrm{P}=0.5$ and $\mathrm{P}=1$, respectively, in the above equation.

The gonadosomatic index $\left(\mathrm{I}_{\mathrm{G}}=\mathrm{W}_{\mathrm{G}} \times \mathrm{W}_{\mathrm{E}}^{-1} \mathrm{x} 100\right)$ and the frequency distribution of gonad maturation stages determined the gonadal cycle. Fish condition was established through the hepatosomatic index $\left(\mathrm{I}_{\mathrm{H}}=\mathrm{W}_{\mathrm{L}} \mathrm{x} \mathrm{W}_{\mathrm{E}}^{-1} \mathrm{x} 100\right)$ and the condition factor $\left(K=\left[W_{E} \times L_{T}^{-1}\right]^{3} \times 1000\right)$. The $I_{G}, I_{H}$, and $K$ were tested for eventual correlation by using the Spearman test $\left(\mathrm{r}_{\mathrm{sp}}\right)$. A KruskalWallis non-parametric test was applied to determine whether temporal (monthly) changes in the means of $\mathrm{I}_{\mathrm{G}}, \mathrm{I}_{\mathrm{H}}$, and $\mathrm{K}$ were significantly different $(\mathrm{p}<0.05)$. Eviscerated weight was used in all calculations to avoid the influence of the contents of the gonad and stomach on the weights. All data are expressed as means \pm standard error.

Fecundity was estimated by the gravimetric method and calculated as follows: $\mathrm{F}=\mathrm{N} \mathrm{x} \mathrm{W} \mathrm{G}_{\mathrm{G}} \mathrm{W}_{\mathrm{GS}}{ }^{-1}$, where $\mathrm{F}=$ fecundity, $\mathrm{N}=$ number of post- vitellogenic oocytes from gonad sub-sample, $\mathrm{W}_{\mathrm{G}}$ = gonad weight and $\mathrm{W}_{\mathrm{GS}}$ = gonad sub-sample weight.

\section{RESULTS}

\section{Gonads Morphology}

Gonads are paired, elongated, covered by a thin peritoneal layer, and range from filiform to piriform in ovaries or from a filiform to a thicker ribbon-like form in testes, depending on the developmental stage (Tab. I). Cranial regions are larger, becoming thinner towards the caudal portion. Each gonad duct lies on the dorsal-medial region. These ducts have a small joint leading to a common orifice. Through the gonads, the arteries occupy a supra-visceral position and spread through lateral ramifications that become evident during gonad development. The right gonad is usually larger than the left. 
Table I. Macroscopic description of gonad stages of M. liza from the Sepetiba Bay.

\begin{tabular}{|c|c|}
\hline Macroscopic & Gonads \\
\hline Immature & $\begin{array}{l}\text { Ovaries and testes are small, filiform, and adhered to the swim-bladder. Both are translucent with no signs of blood } \\
\text { irrigation. }\end{array}$ \\
\hline Developing & $\begin{array}{l}\text { Ovaries are rounder and wider when compared with the previous stage, occupying almost } 1 / 3 \text { of the abdominal } \\
\text { cavity. They are fusiform and reddish in color. Testes are wider than at the previous stage, with thin edges and a } \\
\text { ribbon like shape occupying almost } 1 / 3 \text { of the abdominal cavity. They are cream to white in color. }\end{array}$ \\
\hline Maturing & $\begin{array}{l}\text { Gonads fill almost } 2 / 3 \text { of the abdominal cavity and the arteries are easily visible. Ovaries are reddish-yellow with } \\
\text { a granular appearance due to the oocytes. Testes are white, developed, and ribbon like in shape. }\end{array}$ \\
\hline Ripe (Running ripe) & $\begin{array}{l}\text { Gonads occupy almost the entire abdominal cavity, and blood irrigation is evident. Ovaries are large, yellow, } \\
\text { smooth in appearance, turgid, and round. Oocytes are easily distinguished macroscopically (as granular). Testes } \\
\text { are milky-white in color (bright), turgid, wider in appearance, and have thicker edges with respect to previous } \\
\text { stage. }\end{array}$ \\
\hline Spent & $\begin{array}{l}\text { Ovaries are purple and wrinkled in appearance. Testes are whitish or transparent, with white patches, and wrinkled } \\
\text { in appearance. }\end{array}$ \\
\hline Recovering/resting & $\begin{array}{l}\text { Gonad wall is thicker and rigid, cream in color, and occupy less than } 1 / 3 \text { of the abdominal cavity. Ovarian mass } \\
\text { is firm and reddish in color. Testes are ribbon like and creamy in color. }\end{array}$ \\
\hline
\end{tabular}

\section{Histological observations}

Immature ovaries contained germ cells (and young oocytes) undergoing profound changes in their nuclear structure, cytoplasm, and membranes. The oocyte development was classified into two stages: the previtellogenic stage (germ cells, young oocytes, and peri-nucleolus oocytes from reserve stock) and the vitellogenic stage (oocytes with lipid vitellogenesis, oocytes with lipid and protein vitellogenesis, and oocytes at the post-vitellogenic stage) (Figs 2-7, Tab. II).

The testes are involved with the tunica albuginea and contain the seminiferous tubules. Internal to the seminiferous tubules are Sertoli cells that surround the cysts formed by spermatogenesis cells, which are all smaller than $10 \mu \mathrm{m}$ (spermatogonia, primary and secondary spermatocytes, spermatids, and spermatozoa). Functionally, the testes were divided into four stages according to cellular type: immature, maturing, functional maturation, and recovering (Figs 8-13, Tab. II).

The size of $M$. liza ranged from 285 to $500 \mathrm{~mm} \mathrm{~L}_{\mathrm{T}}$ for males $(n=89)$ and 325 to $690 \mathrm{~mm} \mathrm{~L}_{T}$ for females $(\mathrm{n}=154)$. The number of females longer than $500 \mathrm{~mm}$ significantly outnumbered the number of males (size class 500-550 $\mathrm{mm} \mathrm{L}_{\mathrm{T}}: 1.0: 2.5$; $\chi_{\alpha=0.05}^{2}=3.85$, d.f. $\left.=1\right)$. The ratio for the entire sample $(\mathrm{n}=243)$ was 1.0 male to 1.73 female $\left(\chi_{\alpha=0.05}=17.38\right.$, d.f. $=1$, Tab. III). The size at maturity $\left(\mathrm{L}_{\mathrm{T} 50}\right)$ for $M$. liza was $350 \mathrm{~mm}$ for females. The $\mathrm{L}_{\mathrm{T} 100}$ was $570 \mathrm{~mm}$ and $550 \mathrm{~mm}$ for females and males, respectively. For males, the $\mathrm{L}_{\mathrm{T} 50}$ was not calculated due to the small number of immature fishes.

The mean $I_{G}$ from examined females showed seasonal differences during the study period $(\mathrm{H}=40.43, \mathrm{p}<0.0001$, Fig. 14). The lowest $I_{G}$ were recorded between October and March $(0.16 \pm 0.02$ to $0.27 \pm 0.05$, respectively); these values then increased in April $(0.6 \pm 0.04)$ and May $(2.87 \pm 1.21)$, peaked in June $(6 \pm 2.0)$, and then dropped sharply in July (3.89 \pm 1.26$)$, August $(2.95 \pm 1.5)$, and September $(0.9 \pm 0.03)$. For males, the mean $I_{G}$ also showed seasonal differences $(H=38.54, p=0.0001$, Fig. 14), with the lowest values between October and March ( 0.08 to $0.03 \pm 0.003$, respectively) and the highest values in June (2.09 \pm 0.59$)$, July $(1.0 \pm 0.01)$, and August $(0.9 \pm 0.01)$.

Ripe/running ripe ovaries were observed between May (25\%) and August (12\%). Spent ovaries were recorded between May (8.8\%) and September (7.7\%). Immature ovaries with germ cells were observed between July (25\%) and February (46.6\%); developing ovaries with yolk vesicle oocytes and recovering/resting ovaries with peri-nucleolus stage oocytes were found throughout the study period. Maturing ovaries with lipid and protein vitellogenesis were observed between April (25\%) and September $(7.7 \%)$. Ripe and spent testes were not observed during the study, but maturing testes with spermatozoa were recorded mostly between March (18.2\%) and June (53.8\%) (Fig. 15).

The mean $\mathrm{I}_{\mathrm{H}}$ and $\mathrm{K}$ showed seasonal differences during the study period for males $\left(\mathrm{I}_{\mathrm{H}}: \mathrm{H}=34.02, \mathrm{p}=0.0004 ; \mathrm{K}: \mathrm{H}=\right.$ 25.38, $\mathrm{p}=0.0080)$ and females $\left(\mathrm{I}_{\mathrm{H}}: \mathrm{H}=57.54, \mathrm{p}<0.0001 ; \mathrm{K}: \mathrm{H}\right.$ $=27.30, \mathrm{p}=0.0041)$ (Fig. 14). From December (1.65 \pm 0.07$)$ onwards, the $\mathrm{I}_{\mathrm{H}}$ for females gradually increased, reaching a peak in June ( $2.30 \pm 0.12)$; the $I_{H}$ then decreased from August (1.68 $\pm 0.13)$ to November $(1.32 \pm 0.06)$, when the lowest value was found. The $\mathrm{I}_{\mathrm{H}}$ for males also increased from December onward, and reached a peak in February $(2.48 \pm 0.11)$. The $\mathrm{I}_{\mathrm{H}}$ then decreased slightly to $2.00 \pm 0.09$ in July and dropped in the subsequent months to the lowest values in November (1.40 \pm 0.06$)$.

The mean $\mathrm{K}$ did not show a well-defined seasonal pattern of variation, and shifted throughout the study period. However, a trend was observed: values were low between June $(8.50 \pm 0.22)$ and November $(8.31 \pm 0.19)$, and high between December $(9.16 \pm 0.22)$ and May $(8.93 \pm 0.19)$ for females; males had low values between July $(8.65 \pm 0.13)$ and January $(8.50 \pm$ $0)$, and high values between February $(9.65 \pm 0.11)$ and June $(8.92 \pm 0.09)$. A significant positive relationship was detected 

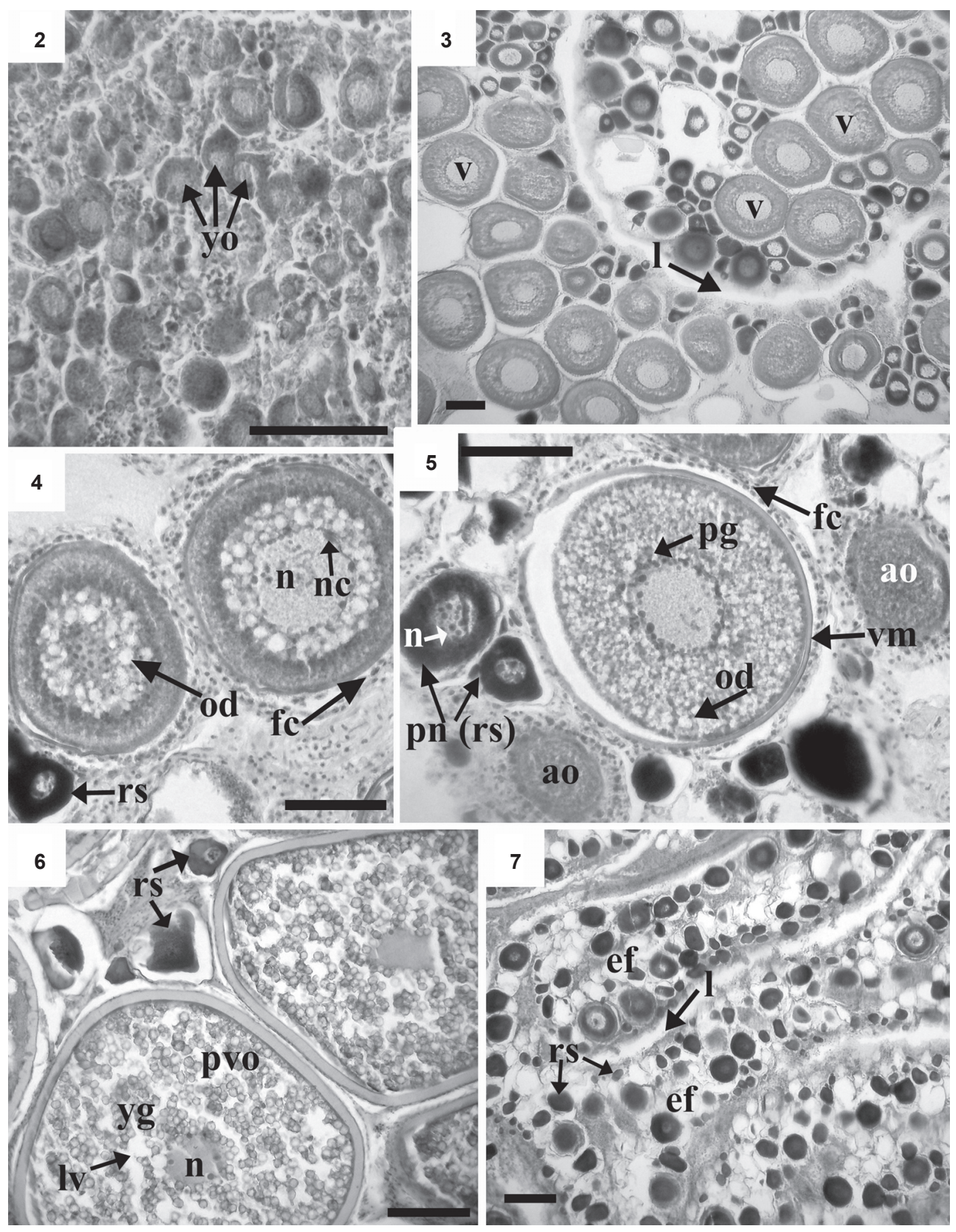

Figures 2-7. Histological sections of ovary at different maturity stages of Mugil liza from Sepetiba Bay: (2) immature ovary containing germ cells and young oocytes; (3) ovary during the vitellogenesis process; (4) developing ovary containing lipid vitellogenesis oocytes; (5) maturing ovary containing lipid and protein vitellogenesis; (6) ripe/running ripe ovary containing post-vitellogenic oocytes; (7) recovering/resting ovary containing empty follicle. (gc) Germ cells, (yo) young oocytes, (rs) reserve stock - peri-nucleolus stage, ( $v$ ) vitellogenic oocyte, (I) lamella, (pn) peri-nucleolus stage, (fc) follicular cells - forming follicular layer, (n) nucleus, (yg) yolk globule, (nc) nucleolus, (od) oil droplet, (pg) protein granules, (vm) vitelline membrane, (ao) atretic oocyte, (pvo) post-vitellogenic oocytes, (Iv) lipid vesicles, (ef) empty follicle. Scale bars: $(2)=50 \mu \mathrm{m},(3,4$ and 7$)=100 \mu \mathrm{m},(5$ and 6$)=150 \mu \mathrm{m}$. 

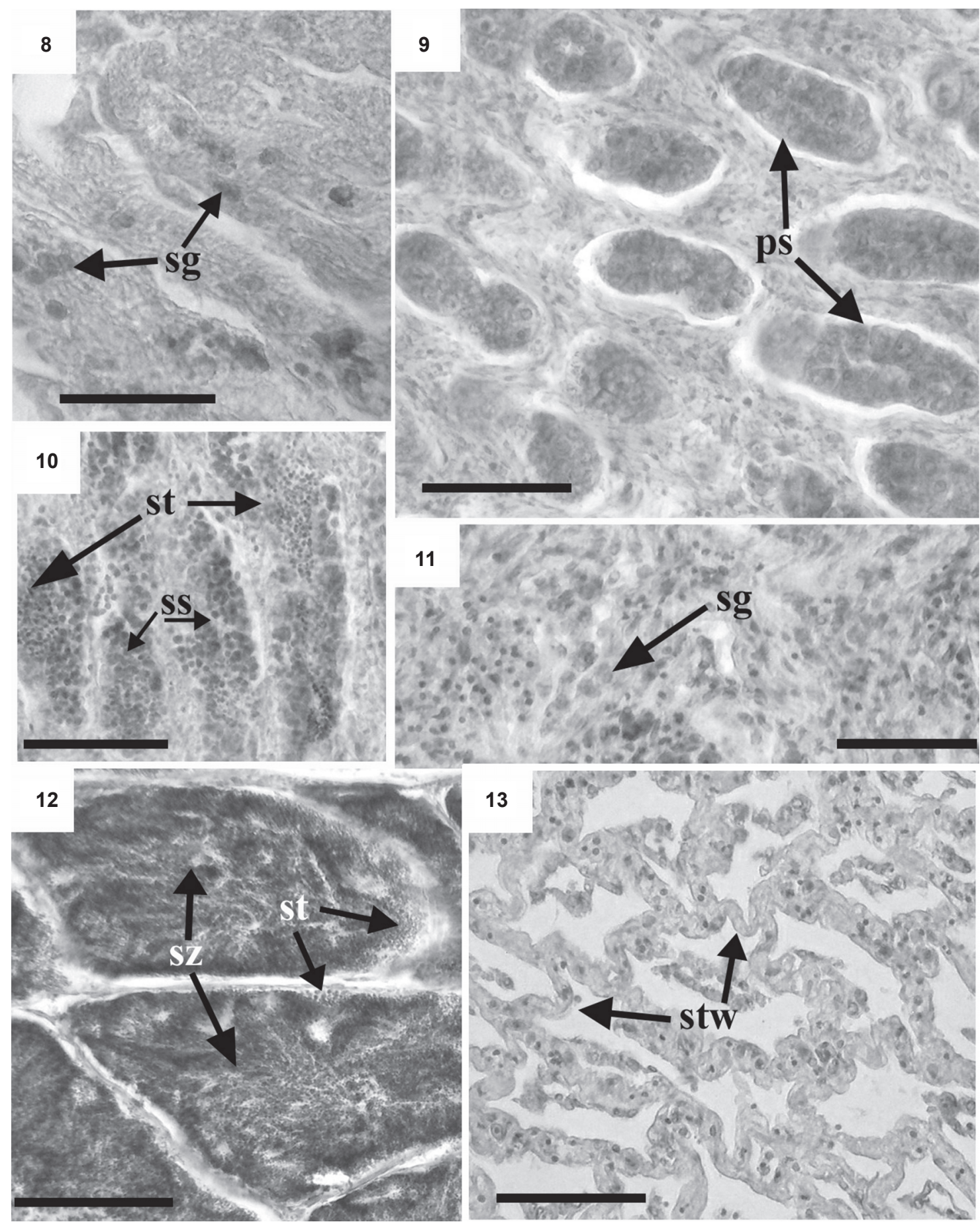

Figures 8-13. Histological sections of testes at different maturity stages of M. liza from Sepetiba Bay: (8) immature testis containing spermatogonia; (9) arrangement of primary spermatocytes forming cysts (maturation stage); (10) arrangement of different testicular cells (maturation stage); (11) maturation stage after recovering stage; (12) spreading pattern of spermatozoa in a ripe/running ripe testis (spermatids are also present in small quantities); (13) recovering testis with seminiferous tubules empty and looser. (sg) Spermatogonia, (ps) primary spermatocytes, (ss) secondary spermatocytes, (st) spermatids, (sz) spermatozoa, (stw) seminiferous tubules wall. Scale bars: $25 \mu \mathrm{m}$. 
Table II. Microscopic description of gametogenesis in M. liza from the Sepetiba Bay.

\begin{tabular}{|c|c|}
\hline Testes & Ovaries \\
\hline $\begin{array}{l}\text { Immature (Fig. } 8 \text { ) - The appearance of sperma- } \\
\text { togonia, the largest cells of the spermatogenic } \\
\text { lineage that are generally associated with the } \\
\text { tunica albuginea, is noted. A volumi-nous nucleus } \\
\text { containing scattered chromatin and several } \\
\text { nucleoli is observed. In recovering testes, the } \\
\text { seminiferous tubules are looser. } \\
\text { Maturation (Figs } 9-11 \text { ) - All stages of cell } \\
\text { development are present after mitotic divisions } \\
\text { from spermatogonia. Spermatocytes are smaller } \\
\text { than spermatogonia. Primary spermatocytes can } \\
\text { form cysts by mitotic division, and the nucleus is } \\
\text { strongly stain ed with ha ematoxylin. The } \\
\text { cytoplasm has little affinity for dyes. Secondary } \\
\text { spermatocytes are somewhat smaller, with a } \\
\text { nucleus that stains weakly. Spermatids are even } \\
\text { smaller than secondary spermatocytes, and their } \\
\text { nuclei have denser chromatin. } \\
\text { Functional maturity (Fig. } 12 \text { ) - Tubules full of } \\
\text { spermatozoa are beginning to accumulate in the } \\
\text { deferent ducts. Spermatids are more visible next } \\
\text { to the walls of the tubules, but all cel types are } \\
\text { present. } \\
\text { Recovering (Fig. } 13 \text { ) - Seminiferous tubules are } \\
\text { looser and empty. Spermatogonia are present, } \\
\text { but no clear signs of spermatocytes, spermatids, } \\
\text { or spermatozoa can be seen. Sertoli cells are easily } \\
\text { visible in the interior region of the seminiferous } \\
\text { tubules. This stage appears after the spent stage } \\
\text { and during the recovering process; seminiferous } \\
\text { tubules will rearrange and begin maturation as } \\
\text { seen in figure } 3 d \text { d. }\end{array}$ & 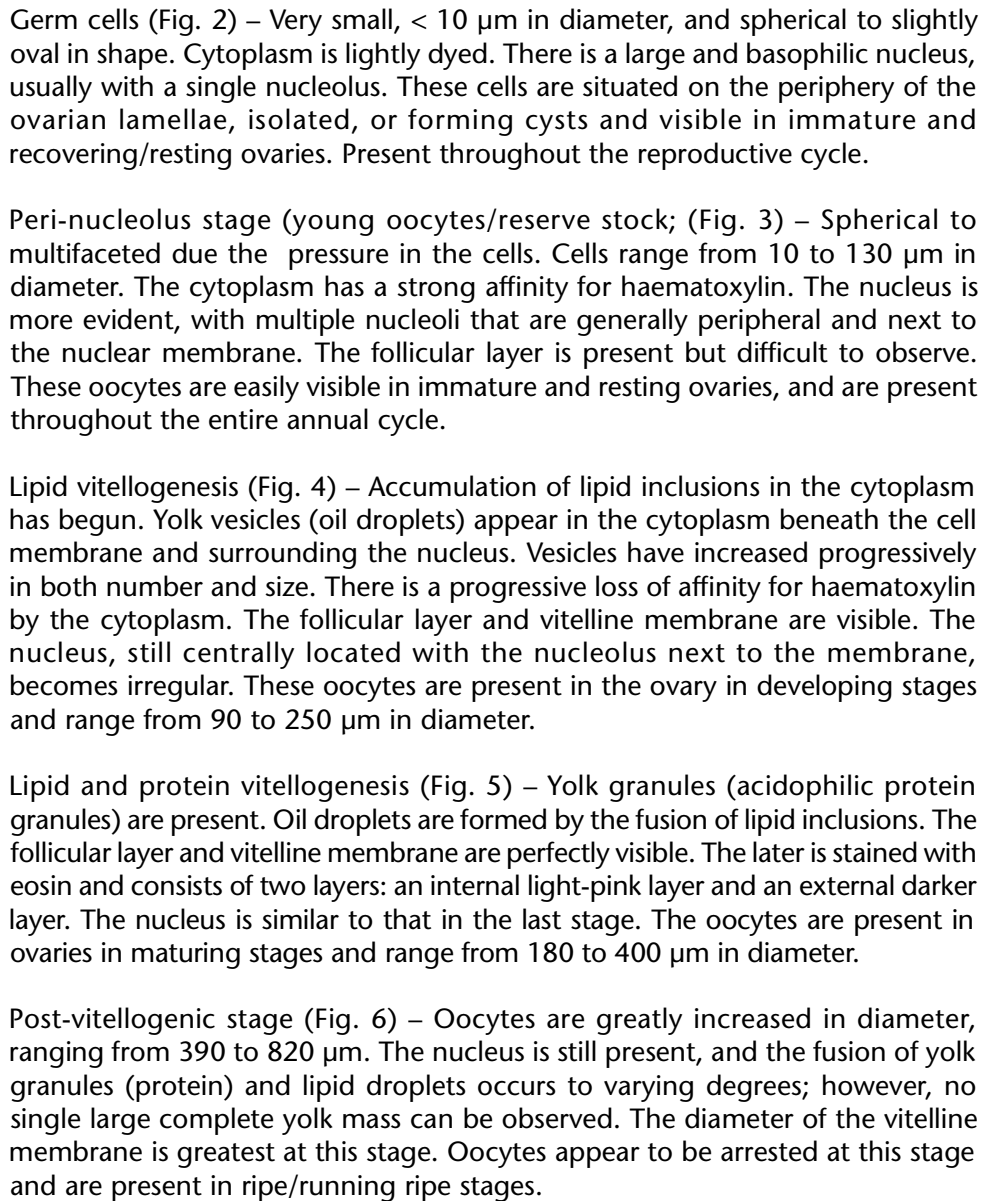 \\
\hline
\end{tabular}

Table III. Chi-square $\left(\chi^{2}\right)$ test for sex ratio comparisons by size classes of M. liza from Sepetiba Bay, 2006/07. (LT) Total length, $(n)$ number of individuals, $\left({ }^{*}\right)$ significant at $95 \%$ level of confidence, (ns) non significant.

\begin{tabular}{ccccc}
\hline $\begin{array}{c}\text { Size Class } \\
(\text { LT mm })\end{array}$ & $\begin{array}{c}\text { Males } \\
(\mathrm{n})\end{array}$ & $\begin{array}{c}\text { Females } \\
(\mathrm{n})\end{array}$ & Total & Significance \\
\hline $300-350$ & 1 & 2 & 3 & $\mathrm{~ns}$ \\
$350-400$ & 3 & 7 & 10 & $\mathrm{~ns}$ \\
$400-450$ & 31 & 35 & 46 & $\mathrm{~ns}$ \\
$450-500$ & 46 & 64 & 110 & $\mathrm{~ns}$ \\
$500-550$ & 6 & 15 & 21 & $*$ \\
$550-600$ & 2 & 13 & 15 & $*$ \\
$600-650$ & 0 & 12 & 12 & $*$ \\
$650-700$ & 0 & 4 & 4 & $*$ \\
\hline Total & 89 & 154 & 243 & $*$ \\
\hline
\end{tabular}

between females' $I_{G}$ and $I_{H}\left(r_{s p}=0.22, p<0.05\right)$, while the $I_{G}$ and $\mathrm{I}_{\mathrm{H}}$ of males were not significantly correlated $\left(\mathrm{r}_{\mathrm{sp}}=-0.04, \mathrm{p}\right.$ $>0.05)$. The $\mathrm{I}_{\mathrm{H}}$ and $\mathrm{K}$ were also significantly correlated for males $\left(\mathrm{r}_{\mathrm{sp}}=0.25, \mathrm{p}<0.05\right)$ and females $\left(\mathrm{r}_{\mathrm{sp}}=0.21, \mathrm{p}<0.05\right)$, but no significant correlation was found between the $\mathrm{I}_{\mathrm{G}}$ and $\mathrm{K}$ for both males $\left(r_{s p}=-0.14, p>0.05\right)$ and females $\left(r_{s p}=0.07, p>0.05\right)$.

Fecundity in M. liza ranged from $241 \times 10^{4}$ to $365 \times 10^{4}$ oocytes per individual. The average fecundity of 20 adults ranging from 590 to $680 \mathrm{~mm} \mathrm{~L}_{\mathrm{T}}$ was $308 \times 10^{4}\left( \pm 104 \times 10^{3}\right)$ oocytes.

\section{DISCUSSION}

Mugil liza testes are classified as the unrestricted spermatogonial type with cystic spermatogenesis, according to the description of GRIER (1981). We have arrived at this classification because spermatogonia occur throughout the seminal lobules, and the spermatocytes consist of a group of synchronously 

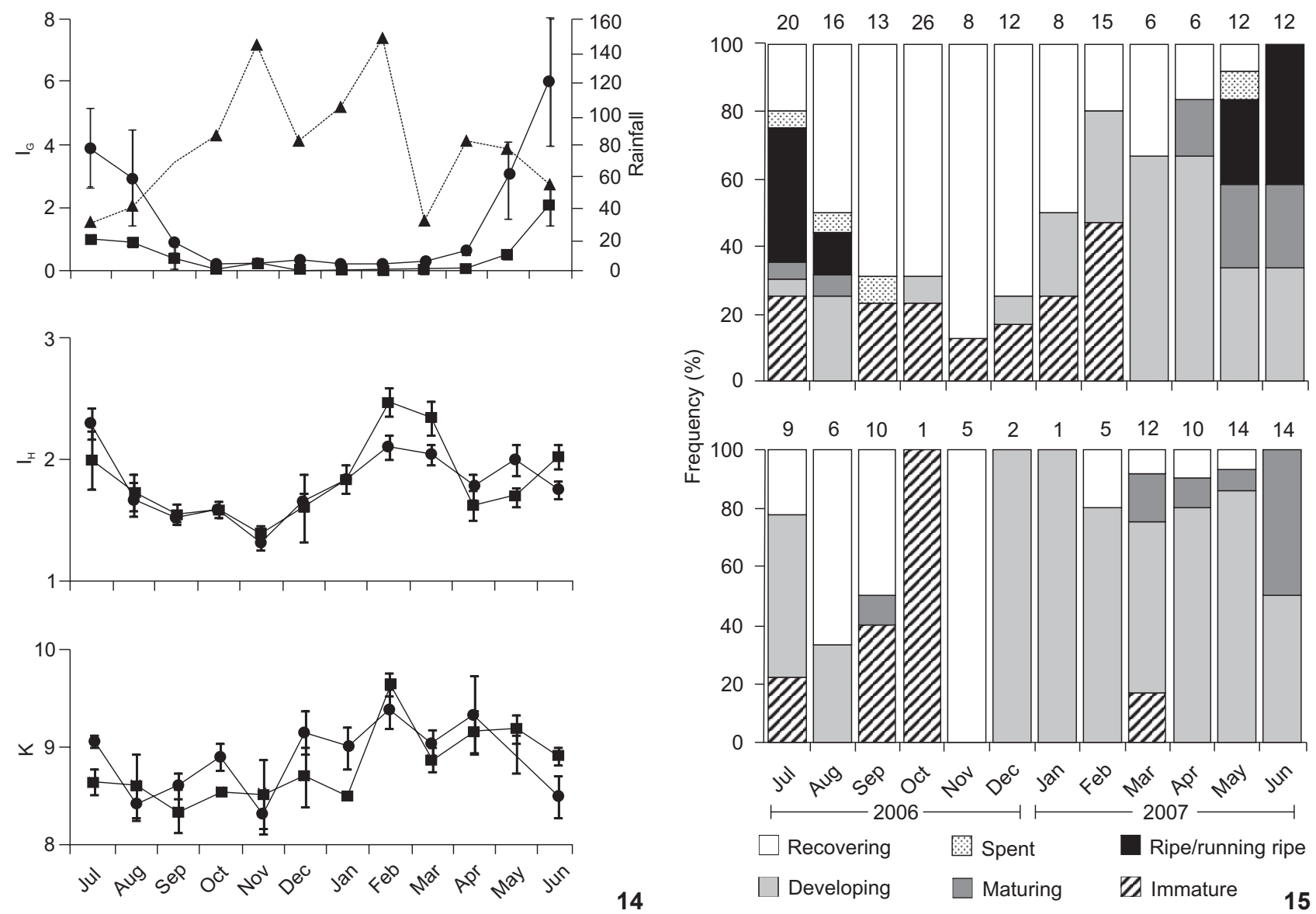

14

Figures 14-15. (14) Monthly changes in rainfall $(\mathbf{\Delta})$, as accumulated $\mathrm{mm}$, and in gonadossomatic index $\left(\mathrm{I}_{\mathrm{G}}\right)$, hepatosomatic index $\left(\mathrm{I}_{H}\right)$ and condition factor (K), as mean \pm s. e., for 89 males $(\boldsymbol{\square})$ and 154 females (0) of M. liza from Sepetiba Bay. (15) Monthly changes in the percent of maturity stages for female (above) and male (below) M. liza from Sepetiba Bay. Samples sizes are given above the bar.

developing germ cells that are encompassed by Sertoli cell cytoplasmic processes.

The development of ovarian tissue can be divided into two phases, as in other teleosts (Wallace \& Selman 1981, Forberg 1982, Howell 1983, Andrade-Talmelli et al. 1996, Solomon \& Ramnarine 2007). During the first phase - the previtellogenic phase - growth is comparatively slow and there are few cytoplasmatic changes. The second phase - the vitellogenic phase - is characterized by faster growth and the deposition of large amounts of yolk in the ooplasma.

Oocytes in the previtellogenic stage (germ cells, young oocytes, or peri-nucleolus oocytes) do not contain yolk and constitute a "reserve fund" for future breeding seasons. The appearance of oil droplets in the cytoplasm (lipid vitellogenesis) is characteristic of the beginning of the vitellogenic phase and indicates that the oocytes will normally continue their development through the remaining stages within the current breeding season. The next stage, lipid and protein vitellogen- esis, is characterized by the appearance of "true" yolk vesicles in the cytoplasm of oocytes. The oocytes increase considerably in size and the yolk accumulates. Vitellogenesis ceases once the oocytes reach their fully developed size, and eventually undergo maturation and ovulation after appropriate hormonal stimulation (Masui \& Clarke 1979).

Histological analyses indicated that the M. liza exhibits synchronous group oocyte development because at least two populations of oocytes can be distinguished in the ovary at the same time during the reproductive cycle (WaLlaCe \& SELMAN 1981). Two clutches of oocytes were present in the ovary of specimens of $M$. liza prior to spawning: a fairly synchronous population of larger oocytes (defined as a "clutch," i.e., post-vitellogenic oocytes) and a more heterogeneous population of smaller oocytes from which the clutch is recruited (germ cells, young oocytes, or peri-nucleolus oocytes). The former are the oocytes to be spawned during the current breeding season, while the latter are the oocytes to be spawned in future breeding seasons. 
In general, the ovaries of multiple spawners have both postovulatory follicles and vitellogenic oocytes simultaneously, after which the postovulatory follicles disappear gradually as the vitellogenic oocytes develop (Hunter \& Goldberg 1980, Hunter \& Macewicz 1985, Murayama et al. 1994). Histological analyses of the ovarian tissue of M. liza did not show such a pattern. Instead, only vitellogenic and peri-nucleolus oocytes (ripe ovaries) or peri-nucleolus oocytes and empty follicles (after the reproductive period in recovering/resting ovaries) were observed. Therefore it can be concluded that M. liza from the Sepetiba Bay is a total spawner and has a similar reproductive pattern to other total spawners in Mugil, such as M. platanus (Andrade-Talmelli et al. 1996, Romagosa et al. 2000) and M. cephalus (McDounough et al. 2003, 2005).

Hydrated oocyte stages and spent ovaries were absent from our histological analysis samples. This may be due to the fact that our samples were collected in the inner zone of the Sepetiba Bay, a rearing and feeding ground for mullets, as described by Silva \& ARaújo (2000). Because mullets spawn offshore (JACOT 1920, ANDERson 1957, DitTy \& Shaw 1996), the small proportion of mature and spent fish in the bay is likely due to the migration of adults to offshore spawning grounds. Moore (1974) also reported that during the spawning period, fully ripe fish are rarely found in coastal and embayment collections.

Mugil liza males are mature $\left(\mathrm{L}_{\mathrm{T} 100}\right)$ at $550 \mathrm{~mm}$, while females have a $\mathrm{L}_{\mathrm{T} 100}=570 \mathrm{~mm}$. In almost all mullet species, males mature earlier than females (Salem \& Mohammad 1983, Geldiay 1977, ОкUмUs \& BASÇNAR 1997), and it appears that the M. liza from the Sepetiba Bay is no exception. Females outnumber males in all size classes, but significant differences in the sex ratio were detected only for sizes larger than $500 \mathrm{~mm} \mathrm{~L}_{\mathrm{T}}$. The ratio of male to female showed an overall proportion of 1.0 male: 1.73 female. It is accepted that the sex ratio is balanced and/or male mullets outnumber females of shorter lengths, while females outnumber males of greater lengths. This phenomenon has been reported for mullets elsewhere (NJOKU \& Ezeibekwe 1996, Okumus \& Basçnar 1997, Ergene 2000, McDounough et al. 2005).

Changes in the sex ratio are common in fish species, with females predominating mostly in larger size classes. The preponderance of females may be a selection to reach higher fecundity (Nikolsky 1963, Gross \& Sargent 1985, Lowe-McConnell 1999). This pattern could also be explained by differences in mortality and growth rates or behavior (WootTon 1990). According to IbaÑez Aguirre et al. (1999), females of M. curema Valenciennes 1836 live five years longer than their conspecific males, and it is likely that M. liza has similar life cycle. However, information on this subject is still lacking. Additionally, Nikolsky (1963) reported that shifts in the sex ratio could occur among populations of the same species and between different periods in a given population; he argued that this behavior is generally an adaptation that assures the predominance of females when environmental conditions are favorable for the production of eggs, or when the species suffers intensive fishing pressure. Since the latter is the case for M. liza, as for other mulletsit is reasonable to hypothesize that overfishing could play a role in the predominance of $M$. liza females in larger size classes.

Mugil liza showed a short reproductive period ranging from May to August. The periodicity of this mullet's reproduction may be related to environmental variability in the signals for optimal early growth and survival. Stability of the water column and suitable food in coastal lagoons, river deltas, and estuarine mangrove areas have been identified as important factors influencing the reproduction and recruitment of juvenile Mugilidae (Yañez-Arancibia 1976, Blaber \& Blaber 1980, Blaber 1987, VieIra 1991). Mugil liza spawns during the dry season when the water column and environmental conditions are stable in the Sepetiba bay. Early juveniles could take advantage of the stable water conditions and abundant food resources that are available in enclosed areas, such as embayments, all year round (MacGregor \& Houde 1996). Silva \& Araújo (2000) reported $M$. liza recruitment from May to October in the Sepetiba Bay, and these findings are in accordance with the spawning period observed in the present work.

Fecundity in $M$. liza is high, ranging from $241 \times 10^{4}$ to $365 \times 10^{4}$ compared with the co-occurring M. curema that shows fecundity between $82 \times 10^{3}$ and $378 \times 10^{3}$ oocytes. Other mullets, such as M. platanus (fecundity $=55 \times 10^{4}$ to $236 \times 10^{4}$ ) and M. cephalus (fecundity $=213 \times 10^{3}$ to $389 \times 10^{4}$ ), also have high fecundity (Romagosa et al. 2000, McDounough et al. 2003, IbáŃEz Aguirre \& Gallardo-Cabello 2004). Fecundity may vary as a result of different adaptations to environmental habitats. In the present study, high fecundity may be associated with the offshore spawning and lack of parental care that are typical of mullets. High fecundity would be a tactic to enable success in $M$. liza recruitment to the Sepetiba bay. These results closely match the findings of Silva \& ARAújo (2000), who recorded large numbers of early juveniles at the inner zones of the bay.

The $\mathrm{I}_{\mathrm{H}}$ and $\mathrm{K}$ have been used to assess fish condition and to relate this condition to reproduction. Several authors have used these parameters, coupled with $\mathrm{I}_{\mathrm{G}}$, to assess the reproductive period (ABASCAL et al. 2004, KANAK \& TACHIHARA 2008), possibly because vitellogenesis and gametogenesis mobilize hepatic energy and body fat (Abascal et al. 2004, KanaK \& Tachinara 2008). Prior to sexual maturation, marine fish generally accumulate large lipid deposits, primarily triacylglycerols, which are subsequently mobilized to support gonad development and spawning migration (BELL 1998). The major lipid storage sites are the mesenteric tissue, muscle, liver, and subdermal fat layers (ACKMAN 1980). In M. liza, the $\mathrm{I}_{\mathrm{H}}$ was positively associated with the $\mathrm{I}_{\mathrm{G}}$, indicating that the liver increases in mass during the reproductive season. Increasing hepatocyte numbers and size is linked to vitellogenesis, since the provisioning of eggs with yolk takes place in the ovaries but the precursors of the yolk are synthesized in the liver (WоOтTON 1990). Additionally, 
the lowest values for the $I_{H}$ were obtained after the end of the spawning season at the time when physical fatigue is greatest and fatty acid reserves are diminished. In conclusion, the $I_{H}$ and $I_{G}$ can be used together to predict the reproductive period of M. liza in the Sepetiba Bay.

In this study, the K was not closely associated with the $I_{G}$. This result may suggest that reproduction does not influence fish condition, which was calculated according to the eviscerated weight of the individuals in this work. Fish in the pre-spawning period (from November through February) had a high concentration of visceral fat (not measured). This phenomenon suggests that visceral fat bodies are likely to be mobilized in late autumn for the purpose of reproduction. KANAK $\&$ TACHIHARA (2008) reported that decreasing visceral fat is associated with vitellogenesis in females. ABASCAL et al. (2004) concluded that fat-body lipid reserves provide an important energy source for gametogenesis in tunas. A lipidosomatic index $\left(\mathrm{I}_{\mathrm{L}}=\right.$ Fat Weight $\left.\mathrm{x} \mathrm{W}_{\mathrm{E}}^{-1}\right)$ could describe the relationship between energy depletion and vitellogenesis better than the K.

Our contribution provides important information on the reproductive biology of $M$. liza that will be helpful in similar studies. Further coordinated laboratory and field studies on the the frequency of spawning, fecundity, and spawning grounds of the same species are necessary for a clearer understanding of the reproduction of this mullet. Based on the biological findings of the present work, it is reasonable to propose that closing the fishing season for M. liza from May to August and setting a minimum size for capture of $350 \mathrm{~mm} \mathrm{~L}_{\mathrm{T}}$ would not only conserve stocks but also increase future harvesting in the Sepetiba bay.

\section{ACKNOWLEDGEMENTS}

We wish to thank Armando Sales and Thatiana P. Ribeiro for being so helpful with the histological analyses. This research was partially funded by CAPES - Brazilian Agency for Higher Studies and Personal Graduation.

\section{LITERATURE CITED}

Abascal F.J.; C. Megina \& A. Medina. 2004. Testicular development in migrant and spawning blue fin tuna (Thunnus thynnus (L.)) from the eastern Atlantic and Mediterranean. Fishery Bulletin 102: 407-417.

AскмAn, R.G. 1980. Fish lipids, part 1, p. 86-103. In: J.J. ConNelL (Ed.). Advances in fish science and technology. England, Fishing News Books Ltd, 528p.

Alvarez-Lajonchere, L. 1979. Algunos aspectos sobre la reproducción de Mugil Liza (Pisces, Mugilidae) en Tunas de Zaza, Cuba. Revista Cubana de Investigaciones Pesqueras 4: 25 61.

Alvarez-Lajonchere, L. 1981. Determinación de la edad y el crecimiento de Mugil liza, M. curema, M. hospes y M. trichodon (Pisces, Mugilidae) en aguas cubanas. Revista de Investigacion Marina 2: 142-162.
ANDERSON, W.W. 1957. Early development, spawning, growth and occurrence of silver mullet (Mugil curema) along the south Atlantic coast of United States. Fishery Bulletin 57: 397-414.

Andrade-Talmelli, E.F.; E. Romagosa; M.Y. Narahara \& H.M. GodinHo. 1996. Características reprodutivas de tainha Mugil platanus (Teleostei, Peciformes, Mugilidae), da região Estuarino-Lagunar de Cananéia, São Paulo. Revista Ceres 43: 165-185.

Araújo, F.G.; M.C.C. Azevedo; M.A. Silva; A.L.M. Pessanha; I.D Gomes \& A.G. Cruz-Filho. 2002. Environmental influences on the demersal fish assemblages in the Sepetiba Bay, Brazil. Estuaries 15: 441-450.

Barbiéri, E.B. \& D.M.P. Kronemberger. 1994. Climatologia do litoral sul-sudeste do estado do Rio de Janeiro (Um subsídio à análise ambiental). IBGE, Caderno de Geociências 12: 57 73.

BELL, J.C. 1998. Current aspects of lipid nutrition in fish farming, p. 114-145. In: K.D. BLACK \& A.D. PICKERING (Eds). Biology of farmed fish. England, Sheffield Academic Press, 429p.

Benetti, D.D. \& E.B.F. Neto. 1991. Preliminary results on growth of mullets (Mugil liza and Mugil curema) fed artificial diets. World-Aquaculture 22: 55-57.

Blaber, S.J.M. \& T.G. Blaber. 1980. Factors affecting the distribution of juvenile estuarine and inshore fish. Journal of Fish Biology 17: 143-162.

BLABER, S.J.M. 1987. Factor influencing recruitment and survival of mugilids in estuaries and coastal waters of Southeastern Africa, p. 507-518. In: M. Dadswell; R. Klauda; C. Saunders; R. Rulifson \& J. Cooper (Eds). Common strategies of anadromous and catadromous fishes. Bethesda, American Fishery Society Symposium, 561p.

Blaber, S.J.M. 2000. Tropical estuarine fishes. ecology, exploitation and conservation. Oxford, Blackwell Science, 372p.

DitTY, J.G. \& R.F. Shaw. 1996. Spatial and temporal distribution of larval striped mullet (Mugil cephalus) and white mullet (Mugil curema, family: Mugilidae) in the northern Gulf of Mexico, with notes on mountain mullet, Agonostomus monticola. Bulletin of Marine Science 59: 271-288.

Ergene, S. 2000. Reproduction characteristics of Thinlip Grey mullet, Liza ramada (Risso, 1826) inhabiting Akgöl-Paradeniz Lagoon (Göksu Delta). Turkish Journal of Zoology 24: 159164.

ForberG, K.G. 1982. A histological study of development in capelin, Mallotus villosus villosus (Muller). Journal of Fish Biology 20: 143-154.

Froese, R. \& D. Pauly. 2008. FishBase. Available online at: http:/ /www.fishbase.org. [Accessed: 01/IX/2008].

GeLDiAY, R. 1977. Ecological aspects of grey mullet living along the coast of Turkey. E.U. Fen Fakultesi Dergisi 2: 155-170.

Grier, H.J. 1981. Cellular organization of the testis and spermatogenesis in fishes. American Zoology 21: 345-357. 
Gross, M.R. \& R.C. SARgENT. 1985. The evolution of male and female parental care in fishes. American Zoology 25: 807-822.

HowelL, W.H. 1983. Seasonal changes in the ovaries of adult yellowtail flounder, Limanda ferruginea. Fishery Bulletin 81: 341-355.

Hunter, J.R. \& S.R. Goldberg. 1980. Spawning incidence and batch fecundity in northern anchovy, Engraulis mordax. Fishery Bulletin 77: 641-652.

Hunter, J.R. \& B.J. Mackiewicz. 1985. Measurement of spawning frequency in multiple spawning fishes, p. 79-94. In: R. LASKER (Ed.). An Egg Production Method for Estimating Spawning Biomass of Pelagic Fish: Application to the Northern Anchovy, Engraulis mordax. La Jolla, NOAA Technical Report NMFS 36.

Ibama. 2005. Estatística da pesca 2005. In: C. Passo; C.E. Calaf \& M.J. TEIXEIRA (Eds). Brasil: grandes regiões e unidades da federação. Brasília, Ministério do Meio Ambiente, Relatório técnico, 108p.

Ibáñez Aguirre, A.L. \& M. Gallardo-Cabello. 2004. Reproduction of Mugil cephalus and Mugil curema (Pisces: Mugilidae) from a coastal lagoon in the Gulf of Mexico. Bulletin of Marine Science 75: 37-49.

IbáÑ̃zz Aguirre, A.L.; M. Gallardo-Cabello \& X.C. Carraca. 1999. Growth analysis of striped mullet, Mugil cephalus and white mullet, M. curema (Pisces: Mugilidade), in the Golf of Mexico. Fishery Bulletin 97: 861-872.

JACOT, A.P. 1920. Age, growth and scale characters of the mullets, Mugil chephalus and Mugil curema. Transactions of the American Microscopical Society 39: 119-229.

KanaK, M.K. \& K. Tachihara. 2008. Reproductive biology of common silver biddy Gerres oyena in Okinawa Island of southern Japan. Fishery Science 74: 265-275.

Katselis, G.; C. Koutsikopoulos; Y. Rogdakis; T. Lachanas; E. Dimitriou $\&$ K. VIDALIS. 2005. A model to estimate the annual production of roes (avgotaracho) of flathead mullet (Mugil cephalus) based on the spawning migration of species. Fishery Research 75: 138-148.

Lowe-Mcconnell R.H. 1999. Estudos ecológicos de comunidades de peixes tropicais. São Paulo, Edusp, 536p.

MacGregor, J.M. \& E.D. Houde. 1996. Onshore-Offshore pattern and variability in distribution and abundance of bay anchovy Anchoa mitchilli eggs and larvae in Cheasapeake Bay. Marine Ecology Progress Series 138: 15-25.

Masui, Y. \& H.J. Clarke. 1979. Oocyte maturation. International Review of Cytology 57: 185-282.

McDonough, C.A.; W. Roumillat \& C.A. Wenner. 2003. Fecundity and spawning season of striped mullet (Mugil cephalus L.) in South Carolina estuaries. Fishery Bulletin 101: 822-834.

McDonough, C.A.; W. Roumillat \& C.A. Wenner. 2005. Sexual differentiation and gonad development in striped mullet
(Mugil cephalus L.) from South Carolina estuaries. Fishery Bulletin 103: 601-619.

Moore, R.H. 1974. General ecology, distribution and relative abundance of Mugil cephalus and Mugil curema on the South Texas Coast. Contribution to Marine Science 18: 241-255.

Murayama,T.; M. Shiraishi \& I. Aoki. 1994. Changes in ovarian development and plasma levels of sex steroid hormones in the wild female Japanese sardine (Sardinops melanostictus) during the spawning period. Journal of Fish Biology 45: 235-245.

Nikolsky, G.V. 1963. The ecology of fishes. London, Academic Press, 352p.

NJoku, D.C. \& I.O. Ezeibekwe. 1996. Age composition and growth of the large-scaled mullet, Liza grandisquamis (Pisces: Mugilidae), Valenciennes, 1836 on the New Calabar Estuary, off the Nigerian coast. Fishery Research 26: 67-73.

Okumus, I. \& N. Basçnar. 1997. Population structure, growth and reproduction of introduced Pacific mullet, Mugil so-iuy, in the Black Sea. Fishery Research 33: 131-137.

Pina, J.V. \& P.T. Chaves. 2005. A pesca de tainha e parati na Baía de Guaratuba, Paraná, Brasil. Acta Biológica Paranaense 34: 103-113.

Romagosa, E.; E.F.A. Talmelli; M.Y. Narahara \& H.M. Godinho. 2000. Tipo de desova e fecundidade da Mugil platanus da região estuarino-lagunar de Cananéia, SP. Atlântica 22: 5-12.

Salem, S.A. \& S.Z. Mohammad. 1983. Study on Mugil seheli and Mugil capito in Lake Timsah: II. Reproduction. Bulletin of the Institute of Oceanography and Fisheries 8: 65-100.

SignoRINI, S.R. 1980. A study of the circulation in bay of Ilha Grande and bay of Sepetiba, part I, a survey of the circulation based on experimental field data. Boletim do Instituto Oceanográfico 29: 41-55.

Silva M.A. \& F.G. Araújo. 2000. Distribuição e abundancia de tainhas e paratis (Osteichthyes, Mugilidae) na Baia de Sepetiba, RJ, Brasil. Revista Brasileira Zoologia 17: 473-480.

Solomon, N.F. \& I.W. Ramnarine. 2007. Reproductive biology of white mullet, Mugil curema (Valenciennes) in the Southern Caribbean. Fishery Research 88: 133-138.

Vieira, J.P. 1991. Juvenile mullets (Pisces: Mugilidae) in the estuary Lagoa dos Patos, RS, Brazil. Copeia 1991: 409-418.

YÁnez-Aracibia, L.A. 1976. Observaciones sobre Mugil curema Valenciennes, em áreas naturales de crianza, maduración, crescimiento, madurez y relaciones ecológicas. Anales del Centro de Ciencias del Mar y Limnologia 2: 211-243.

Wallace, R.A. \& K. Selman. 1981. Cellular and dynamic aspects of oocyte growth in teleosts. American Zoology 21: 325-343.

WeSt, G. 1990. Methods of assessing ovarian development in fishes: a review. Australian Journal of Freshwater Research 88: 775-786.

Wootton, R.J. 1990. Ecology of teleost fishes. London, Chapman and Hall, 404p.

Submitted: 17.III.2009; Accepted: 28.IV.2010.

Editorial responsibility: Rosana Mazzoni

ZOOLOGIA 27 (3): 331-340, June, 2010 